\title{
Facing the Chaos of Today's World: Life Design as a New Concept of Counselling for New Times
}

\author{
Violetta Drabik-Podgórna / e-mail: violetta.drabik-podgorna@uwr.edu.pl \\ Institute of Pedagogy, University of Wrocław, Polska
}

Drabik-Podgórna, V. (2020). Facing the Chaos of Today's World: Life Design as a New Concept of Counselling for New Times. Czech-Polish Historical and Pedagogical Journal, $12 / 2,30-42$.

https://doi.org/10.5817/cphpj-2020-020

My goal in this paper is to present what is referred to as the life design paradigm as a new, viable approach to career design which takes into account the new contexts cursorily outlined above. Drawing on the notion of chaos as a tool for describing today's world, I seek to show how the concept can help us conceptualise the changing systems of work organisation, people's biographies and applicatory potentials of career counselling theories. By doing this, I to make the case for the pertinence and utility of the intervention model proposed by Mark L. Savickas and his collaborators.

Key words: chaos; segmentation of the labour market; biographical chaos; life- and careerconstruction counselling / Life Design

Issues involved in designing career paths are not only pivotal to reflection undertaken in counselling studies but also central to very real challenges which must be handled by young people when choosing schools or entering the labour market and by adults when seeking new employment options and promotion possibilities as employees or, for that matter, recruiting employees as employers. Related challenges must also be addressed by career professionals whose responsibilities include supporting various client groups in their personal and vocational development. Despite the availability of brilliant technologies, successful coping with these difficulties seems to be increasingly difficult in our ever more complex and complicated world. All this begs several questions, such as: Is it at all possible to plan and design the future? What are effective ways of helping people design their careers? How can we productively respond to the expectations of support-seeking clients?

\section{The notion of chaos and its relevance in current scholarship}

The word 'chaos' stems from the Greek Xóos, which originally denoted the void. In mythology, chaos was the embodiment of the primaeval emptiness - the formless, elementary state of matter before the universe became ordered. Chaos 
was also depicted as an abysmal chasm (in contrast to the earth with its stable ground, which emerged from it); as a gaping space with no fixed directions (where everything fell to all sides); and as a dividing gap (between the heaven and the earth). ${ }^{1}$

The Polish Internetowy Słownik Synonimów (Internet Synonym Dictionary) lists 391 synonyms and near-synonyms of 'chaos', which are grouped in twenty-five semantic categories, including notions as different as: $1 /$ mess; $2 /$ free-for-all; 3 / disorder; 4/ havoc; 5/ confusion; 6/ grappling with difficulties; 7/ clutter; 8/ disorganisation and lack of planning; 9/ trouble-making; 10/ muddle; 11/ drumming up; and 12/ lawlessness. ${ }^{2}$

While the most frequent colloquial connotations of chaos include mess, disorganisation and the lack of clarity, contemporary scholarship conceives of chaos in strikingly different and productive ways. In recent years, chaos has been elevated into a captivating category for describing the world in manners that remodel our thinking of about predictability and repeatability. Specifically, it has been recognised that the world is governed by multiple chaotic systems, while determinist systems are in fact exceptions to the rule, rather than the rule as such. Furthermore, chaos is actually bound up with order and worlds apart from chance/randomness. Given these considerations, the notion of determinist chaos has been crafted. ${ }^{3}$

Roman Duda notices that: The mathematical science of chaos overcomes the barriers dividing disciplines, bringing together researchers from multiple fields of scholarship. As a science studying the global structure of systems, it also reverses the previously prevalent reductionist tendency in which a phenomenon is broken down into its constituent parts, and thereby opens up a holistic perspective, paving the path to the science of totality (...) Chaos theory has unexpectedly revealed the common ground of two distinct paradigms of the mathematical description of the world: the determinist one (differential equations) and the probabilistic one (stochastic processes and statistics). As harmony and dissonance amalgamate into musical beauty, so order and chaos coalesce into mathematical beauty. ${ }^{4}$

Because we are not an expert on chaos theory, my aim in this paper is not to produce a detailed account of its assumptions or to explain its central notions (e.g. fractal, attractor, bifurcation and entropy). As a counselling studies scholar, I only

1 Grimal, P. (1987). The Dictionary of Classical Mythology. Oxford: Blackwell, p. 61.

2 Synonim.net - Internetowy Słownik Synonimów. Entry "chaos": https://synonim.net/ synonim/chaos. Retrieved 8 October 2018. For a corresponding range of English synonyms and near-synonyms of "chaos," see e.g. Thesaurus.com (https://www.thesaurus.com/ browse/chaos).

3 Cf. Snopek, M. (2017). Teoria chaosu jako narzędzie badawcze w naukach o bezpieczeństwie. Bezpieczeństwo i Technika Pożarnicza. Vol. 4(3), pp. 81-84.

4 Duda, R. (2005). Matematyka a chaos. In Chmielewski A. (Ed.) Jubileusz Trzechsetlecia Uniwersytetu Wrocławskiego 1702-2002, Wrocław: Wyd. U.Wr, p. 34. 
examine certain tendencies that surface in my research field and scrutinise endeavours to apply a range of concepts with a view to explaining the phenomenon of helping in the contemporary world. As Michał Tempczyk insists, despite its name, chaos theory is by no means a scientific theory the traditional meaning of the term, as opposed to the theory of evolution, the theory of elementary particles, the theory of social structures or sundry economic theories. Rather, chaos theory is a very broad research movement which avails itself of very diversified methods and probes highly varied thematic clusters. ${ }^{5}$

Distinctive to chaos theory is that it adopts the complexity perspective to investigate the world and, hence, is also referred to as complexity theory. As such, it is not restricted to the solid sciences and can be employed in multiple disciplines. Its fruitful applicability has already been amply documented in the social sciences. It has served to study voter preferences in the political sciences and is broadly used in the economy to understand market processes and investor behaviour, to improve planning and to calibrate marketing research. ${ }^{6}$

Attempts to apply chaos theory in the study of career counselling have also been undertaken. One of the chaos theory pioneers in this field is Danielle RiverinSimard, a Canadian researcher based in Quebec, who put forward the concept of vocational chaos in he paper published in the prestigious French journal L'Orientation Scolaire et Professionnelle in 1996. ${ }^{7}$ In her discussion of new tendencies in counselling theories, Ewa Solarczyk-Ambrozik outlines the Chaos Theory of Careers (CTC) proposed by Robert Pryor and Jim Bright ${ }^{8}$ as a remarkably productive contribution to the development of reflection on career counselling. ${ }^{9}$ Ewa Sarzyńska-Mazurek also draws on chaos theory in her analysis of random episodes in careers of career counsellors. ${ }^{10}$ While such applications of complexity theory in counselling scholarship are rather likely to expand and multiply soon, they are still rather few and far between, yet their insights are fairly appealing. I will revisit

5 Tempczyk, M. (2002). Teoria chaosu dla odważnych. Warszawa: PWN, p. 7.

6 Cf. Kruszewski, R. (2014). Heterogeniczne oczekiwania a konkurencja doskonała: model matematyczny. Zeszyty Naukowe Uniwersytetu Szczecińskiego. Studia i Prace Wydziału Nauk Ekonomicznych i Zarzadzania. Vol. 2(35), pp. 125-137; Wyciślak, S. (2009). Wykorzystanie teorii chaosu w zarządzaniu przedsiębiorstwem. Organizacja i kierowanie. Vol. 1, pp. 37-50; Peters, E. (1994). Fractal market analysis: applying chaos theory to investment and economics. New York: John Wiley \& Sons.

7 Riverin-Simard, D. (1996). Le concept du chaos vocationnel: un pas theorique a l'aube du XXI-e siecle? Lorientation scolaire et professionnelle. Vol. 25(4), pp. 467-487.

8 Pryor, R. - Brihgt, J. (2001). The chaos theory of careers. New perspective on working in twenty-first century. New York: Routledge.

9 Solarczyk-Ambrozik, E. (2015). Nowe trendy w teoriach rozwoju karier - implikacje dla poradnictwa kariery. Studia Edukacyjne. Vol. 35, pp. 21-53.

10 Sarzyńska-Mazurek, E. (2013). Perspektywa przypadkowych zdarzeń w karierach doradców zawodowych, Lublin: Wyd. UMCS. 
this point further in my argument, but for now I will focus on how chaos/complexity are framed in two contexts. One of them involves systems of work organisation which coexist on the market, and the other concerns people's biographies.

\section{The labour market in the new chaotic times}

No discussion of systems of work organisation is complete without an account of transformations on the labour market. In their historical overview building on Alain Tournaine's framework, ${ }^{11}$ Jean Guichard and Michel Huteau define these changes as a transition from the professional model through Fordism and the technical model to 'vocational chaos.' 12 Each of them requires different kinds of work activities and skills, differently defines qualifications and thus differently envisages ways of achieving them/education paths. Such an evolution re-casts the aims and responsibilities of career counselling.

The professional system of work organisation arose in the early $20^{\text {th }}$ century and essentially resembled the crafts model. Individuals underwent a long-lasting training process to acquire a certain pre-defined capital of knowledge and skills, which was referred to as a profession, served as the foundation of their identities and guaranteed stability in life. As long-term training for work was obviously a costly venture, the choice of the future occupational path was a serious matter that called for tried and tested, reliable diagnostic methods to identify people's capacities and interests and match them with job requirements. This was the setting for the rise of classic vocational guidance with its fundamental aim of helping people choose a vocation once and for all.

Henry Ford's inventions, including the assembly line, revolutionised the system of production. For this reason, the following model of work organisation has been labelled Fordist. As production was split into stages, work was reduced to the performance of a series of basic activities at the pace imposed by the speed of the assembly line. It did not take long years of training to master the skills necessary at a given work stand. Brief, on-the-job training was enough. Consequently, individuals no longer possessed vocations or professions, and as such could not found their identities on them, instead becoming operators. Rather than being people's property, skills were ascribed to particular work positions. Any change of stand or position entailed having to learn from scratch and to master new operations indispensable for performing new tasks. ${ }^{13}$ Efficiency demanded that individuals not only adjust to the physical conditions of work but also adapt to

11 Touraine, A. (1995). La qualification du travail: histoire d'une notion. Journal de psychologie normal et pathologique. Vol. 13, pp. 27-76.

12 Cf. Guichard, J. - Huteau, M. (2005). Psychologia orientacji i poradnictwa zawodowego. Kraków: Impuls, pp. 9-15.

13 Ibid., p. 11. 
worker collectives. Team work became essential, involving having shared interests and values. With such developments in place, counselling had a new responsibility of facilitating occupational adjustment/adaptation, Given this, methods based on the criteria of values, interests and occupational typologies were widely employed.

Closing Touraine's historical account, the competence (or technical) system of work organisation emerged concomitantly with the automation of production processes and the globalisation of production. In these realities, the importance of various intersectional skills associated with interactions arising at work, rather than with particular jobs, increased, and individuals were expected to display teamwork skills, capacity to handle time pressure, communicativeness, flexibility, etc. ${ }^{14}$ Thusconceived competences added up to career capital, i.e. 'the subjectively perceived value of personal resources which enable individuals to achieve and sustain their employability. ${ }^{15}$ Workplace-related activities were not circumscribed by a vocation, a work stand or a position but, instead, formed a work function which incessantly evolved, because employees were regarded as people furnished with a competence capital and capable of expanding it. Furthermore, as competences acquired in some areas could be transposed onto other ones, they were both transversal and transferable. Such transformations triggered another change in the tasks of counselling, which on the one hand helped examine and survey various competences developed in different contexts and on the other engaged in career education in order to prepare young people for navigating the labour market.

The turn of the $20^{\text {th }}$ century brought about new, far-ranging changes which have since re-drawn the labour market. The accelerated development of cuttingedge technologies, robotisation and cyborgisation have combined with global challenges, environmental disasters, exacerbating social inequalities, the delocalisation and flexibilisation of work, changes in labour law, the general instability of life and the unpredictability of events to further increase the complexity of the labour marked and to cause its considerable segmentation. ${ }^{16}$ The primary sector, which offers attractive and well-paid employment both to technical workers (the lower market) and university-educated employees (the upper market), coexists with the secondary sector, which includes a growing class of people whom Guy Standing designates as the precariat. ${ }^{17}$ The precarians most frequently hail from groups at risk of social exclusion, such as people with disabilities, migrants, women re-entering the labour market after extended family breaks, the elderly, school drop-outs, NEETS, ${ }^{18}$ etc. In the current conjuncture,

$14 \quad$ Ibid., p. 13.

15 Bańka, A. (2007). Psychologiczne doradztwo karier. Poznań: PrintB, p. 64.

16 Guichard, J. - Huteau, M. Op. cit., p. 14.

17 Standing, G. (2019). Prekariat. Nowa niebezpieczna klasa. Warszawa: PWN.

18 An acronym of "not in employment, education or training," NEET denotes young people aged 20-34 years who have no jobs, are not involved in schooling and do not undergo any vocational training. 
jobs which guarantee considerable social prestige co-exist with work which neither provides reliable livelihoods nor ensures decent lives, and the shrinking employment market forces people to interrupt their careers and engage in activities in which remuneration is not based on money exchange. These processes generate what Guichard and Huteau refer to as 'vocational chaos. ${ }^{19}$

Another feature of chaos that pervades today's market is that all the systems of work organisation listed above exist alongside each other. While, admittedly, the competence system prevails, the fields in which people's jobs continue to be performed within the professional system have by no means vanished (this is true both for some classic crafts and for professions, such as medical doctor, teacher or lawyer). Simultaneously, big production plants where work conforms with the Fordist system are still around as well. All this makes people, who live in conditions of dispersed insecurity, all the more confused and unable to decide which options offered by the market are optimal for them.

Additionally, entirely novel enterprises arise. This tendency is exemplified by so-called turquoise organisations, which relinquish hierarchical management altogether, whereby they thoroughly alter the previously common model. A turquoise organisation is founded on collaboration, where all workers form the company together and jointly bear responsibility for it. As there are no bosses or superiors, nobody issues orders and nobody calls people to account (or rewards them, for that matter), because every worker knows what his/her duties are, what targets s/he pursues and what values should guide his/her actions. Given this, turquoise organisations require a special set of competences, e.g. self-reliance, selfawareness, trust, honesty and responsibility. What comes to matter even more is the worker's personality and factors such as the sense of community, teamwork, collaborative decision-making and faith in people. Major motivations in turquoise organisations include a good atmosphere at the workplace, the sense of agency, self-esteem and having a say in company-related issues (everybody's voice matters).$^{20}$ Regrettably, this organisation system is not widespread since it hinges on workers' remarkable maturity. In order to prepare people for working in this way, the entire education and training system would have to be revamped as it is now informed by an utter distrust toward students and is based on the constant testing of their progress, exams, punishments and rewards, rivalry and competition. ${ }^{21}$

19 Guichard, J. - Huteau, M. Op. cit., p. 14.

20 Cf. Laloux, F. (2015). Pracować inaczej. Warszawa: Wydawnictwo Studio EMKA.

21 Incessant control and distrust at school are best exemplified by commonly used, unannounced quizzes. This method is underpinned by the belief that without quizzing students would not learn. As a result, students are motivated by a fear of unexpected tests, rather than driven by a desire to augment their knowledge or simply by curiosity about the world and people. Habits instilled at school are transferred to universities and later to workplaces. 
To recapitulate, the labour market today is by no means uniform or homogeneous; instead, there is a multiplicity of complex and diverse markets, which results in varying expectations and the demand for different kinds of competences. Additionally, the coronavirus pandemic has triggered a global economic crisis as abruptly imposed rigorous lockdown measures have caused immense economic losses and a dramatic surge of unemployment rates. Consequently, counselling is faced with a challenge of offering interventions which will help people find their bearings and their place in the emergent reality.

\section{New times and biographical chaos}

People's biographies are explored in a range of disciplines. The study of life histories and recurrent life patterns or scripts across centuries is compelling to historians, psychologists, social scientists and educators alike. Of course, human lives have ever been simple or predictable, yet currently the level of insecurity, complexity and mutability seems to be peeking. Saving people's lives has become the most essential issue in the face of the coronavirus outbreak, and curbing the spread of the disease could only be accomplished in one way - by locking people up at homes. As countless businesses have been closed down and numerous work activities have been transferred 'into the cloud,' new financial, social and mental problems have proliferated. Planning anything in such circumstances seems to be a game of unpredictable results and inscrutable rules. The world we inhabit has veritably become VUCA: volatile, uncertain, complex and ambiguous. ${ }^{22}$

The theories of vocational development proposed in the $20^{\text {th }}$ century described it as a predictable and ordered process arranged in a sequence of well-defined stages. According to Erik Erikson, the development of identity was bound up with solving conflicts typical of given age groups. ${ }^{23}$ Eli Ginzberg, Sol Ginzburg, Sidney Axelrad and John Herma envisioned this development as a passage from imaginations to realism. ${ }^{24}$ Similarly, Bernadette Dumora argued that comparative, probabilistic and implicative considerations led young people from magical and tautological thinking ("If I want something, I can do it) to real and realistic decisions. ${ }^{25}$ Linda Gottfredson identified stages in the formation of a cognitive

22 The acronym VUCA was first used in 1987 in relation to leadership theories of Warren Bennis and Burt Nanus to capture the post-Cold War situation characterised by volatility, uncertainty, complexity and ambiguity. Cf. Cztery sposoby na zarządzanie w świecie VUCA, https://zmiana.edu.pl/4-sposoby-zarzadzanie-swiecie-vuca/ (Retrieved May 2020).

23 Cf. Erikson, E. (2004). Tożsamość a cykl życia. Poznań: Wyd. Zysk i S-ka.

24 Cf. Ginzberg, E. - Ginzburg, S. - Axelrad, S. - Herma, J. (1995). Occupational Choice: An Approach to a General Theory. New York: Columbia University Press.

25 Cf. Dumora, B. (1990). La dynamique vocationnelle chez l'adolescent du collège: continuité et ruptures. L'Orientation Scolaire et Professionnelle. Vol. 19, pp. 111-127. 
map of occupations, ${ }^{26}$ and Donald Super, the founder of the life-course and lifespace framework, famously described maxi and mini developmental cycles. ${ }^{27}$

An interesting, albeit little known, concept was proposed by Riverin-Simard, who examined vocational trajectories of adults. She framed them as a journey in the outer space from planet School via planet Work to planet Retirement, unfolding in three major stages. The first stage involved landing and exploration (23-37 years of age), as people transitioned from school to work and entered the labour market (23-27), searched for the most promising vocational path (28-32) and engaged in the career race (33-37). The second stage revolved around reflection and distancing (38-52). People looked for new guidelines (38-42), tried to identify the leitmotif of their occupational histories (43-47) and modified trajectories (48-52). In the last stage of their careers, people moved from planet Work to planet Retirement. They attempted to find a promising exit (53-57), entered the 'gravitational field' of planet Retirement (58-62) and actually retired (63-67). ${ }^{28}$

In a similar vein, careers were conceptualised as promotion and the development of competences (from basic to advanced). Starting their jobs, individuals knew what to expect, they could plan their work lives and enjoyed a relative sense of stability and security. Careers were like anchors, because they were attached to one occupation and were implemented within one company until retirement. ${ }^{29}$

These frameworks were founded on scientific arguments which, as rightly observed by Guichard, were sound, but only in the contexts in which they were formulated and only for people whom they were supposed to serve. ${ }^{30}$ In the VUCA world, however, future planning cannot be based on previous experiences, because the pace and the multi-directionality of changes invalidate our prior insights. Today, work trajectories are increasingly frequently based on short-term contracts, and people are employed for fixed terms or on the project-to-project basis. As a result, such trajectories resemble vocational chaos rather than a well-ordered structure. Linear analyses of career paths do not help understand people's experiences; it is only by looking through the lens of what destroys, ruptures and loops over linearity $\left(\right.$ transitions ${ }^{31}$ ) that the complexity of processes at hand can be grasped.

26 Gottfredson, L. S. (1981). Circumscription and compromise: A developmental theory of occupational aspirations. Journal of Counseling Psychology. Vol. 28(6), pp. 545-579.

Cf. Super, D. (1957). The Psychology of Careers. New York: Harper \& Row.

Cf. Riverin-Simard, D. (1984). Etapes de vie au travail. Montreal, Quebec: Saint Martin.

Cf. Domecka, M. - Mrozowicki, A. (2008). Robotnicy i ludzie biznesu: wzory karier zawodowych a zmiana społeczna w Polsce. Przegląd Socjologii Jakościowej. Vol. 4/1, pp. 136-155. interventions. Studia Poradoznawcze/ Journal of Counsellogy". Vol. 7, pp. 267-304.

31 Schlossberg, N. K. (1981). A model for analyzing human adaptation. The Counseling Psychologist. Vol. 9 (no. 2), pp. 2-18. 
Given this, the study of contemporary careers abandons linear causality for the sake of non-linear dynamics (Savickas et al., 2009, p. 243). Career tends to be perceived as a mosaic of life episodes, ${ }^{32}$ as assuming a patchwork-like form and as comprised of various, often incoherent, incompatible, random and apparently chaotic experiences. According to Markieta Domecka and Adam Mrozowicki, such a career model neither results from any personal plan nor is an outcome of conscious choice. Rather, it ensues from chaos that prevails in other spheres of life and from the difficulties which individuals experience and with which they strive to cope by whatever means available. Such careers are situationally constructed and involve externally enforced job changes or simultaneous performance of varied work activities which have little in common in terms of both industries and people's competences. ${ }^{33}$

\section{Life design: A new concept of career and life counselling}

As already mentioned, the concepts of career development proposed in the $20^{\text {th }}$ century presupposed a certain predictability and the sequential line-up of stages in vocational development. This no longer corresponds to the currently observable biographical patterns. As transitions multiply and become inevitable, the experiences of people in the VUCA world become ever more complicated and the frameworks which fit the previous century are simply insufficient. The theories that envision human characteristics as permanent and fixed, individuals as passive and external mobilisation as indispensable (e.g. the frameworks proposed by Frank Parsons and John Holland) cannot but fail to meet contemporary people's needs, but - alas! - continue to be eagerly used by Polish career counsellors in their daily practice. Attachment to these classic models and, worse even, blending their de-contextualised elements are fundamental flaws of classic vocational counselling. Such helping interventions are doomed to be ineffective since these theories preclude understanding the position and problems of clients who seek professional support today.

New times call for new theories. By interpreting the mosaic-like complexity of individual experiences through the lens of the chaos theory of careers, we may be able to discern a certain order. The variety and contingency of experiences do not have to produce negative consequences. They may be outcomes of intentional pursuits and of a calculated effort to found one's identity on what so-called fate and chance bring. All this can be framed as a deliberate project and a consciously assembled construction: ${ }^{34}$ 'Such a career model is usually comprised of a series of

32 Wojtasik, B. (2003). Refleksyjne konstruowanie kariery życiowej w ponowoczesnej codzienności. Teraźniejszość-Człowiek-Edukacja., Special Issue, pp. 343-352.

33 Domecka, M. - Mrozowicki, A., Op. cit, p. 144.

34 Cf. Ibid., p. 147. 
vertical and horizontal moves within one or several organisations and of meaningful turning points which re-direct the career course, give it a momentum and open up new prospects of career development. ${ }^{35}$

Given the multiplicity of possible career models, shifts and breaks in careers (transitions) combined with the impossibility to predict and plan the future, a turn to chaos theory has also been registered in counselling research. Prior and Bright's chaos theory of careers (CTS), the most widely resonant endeavour of this kind, holds that both individuals and communities are complex, open, adaptive and change-sensitive systems: 'Chaos theory affords insights into complexity, adaptivity, change, chances, non-linearity, creativity and history as systemic features of individuals and communities. ${ }^{36}$ This framework brings together seemingly divergent constructivist, contextual and systems approaches, perceiving individuals as capable of constructing their careers through causal actions which may be ostensibly inappropriate, maladjusted, driven by unrecognised motives and rationalised by defence mechanisms.

Riverin-Simard had to revise her concept of career development from the 1980s. As she continued her research, she came to realise that career course was far more complicated and less predictable than she had believed. Long before John D. Krumboltz's theory of planned happenstance ${ }^{37}$ and Prior and Bright's CTC, she employed deterministic chaos theory in counselling and concluded that disturbances in career continuity displayed a certain structure. ${ }^{38}$ She has ever since repeatedly emphasised that people today live amidst vocational chaos and has sought ways of capturing, comprehending and structuring this observable instability. If chaos does not equal randomness, disruptions of continuity do not have to be destructive, but may represent 'a mode of expressing reality whose structure still evades our understanding. ${ }^{39}$ The seeming disarray of career paths may be underpinned by a certain order, and the ostensibly haphazard biographical ruptures may make sense in the developmental phases in which they occur. More than that, disturbances themselves (construed as transitions in the counsellingstudies context) may have their structure, be uncoincidental and not depend on chance circumstances.

Individuals sometimes consciously embrace chaos; they take risks, intensify their pursuits and discard entrenched tried-and-tested scripts. In such cases, the disruption of continuity, opaqueness and demobilisation may be deliberate and may serve to further the intentional de-construction and re-construction of

\footnotetext{
35 Ibid.

36 Solarczyk-Ambrozik, E., Op. cit. p. 39.

37 Krumboltz, J. D. (2009). The Happenstance Learning Theory. Journal of Career Assessment. Vol. 17(no. 2), pp. 135-154.

38 Riverin-Simard, D. Le concept du chaos..., p. 484.

39 Cf. Lachelier, J. (1992). Du fondement de I'induction. Paris: Fayard.
} 
previously adopted action patterns. Transitions on the one hand undermine stability and even breed anxiety, but on the other they are processes in which change is forged ${ }^{40}$ and which are not necessarily obstacles to but sometimes rather triggers of individual development and life balance. Everyday work and non-work experiences of adults in the $21^{\text {st }}$ century entail ongoing vocational transitions, the continuing imperative of flexible adaptation to the changing conditions and, above all, incessant grappling with inner quandaries and dilemmas concerning their entire life-space.

Life design counselling, collaboratively developed by a group of scholars led by Mark L. Savickas, merits special recognition as a framework that meets the needs of the VUCA world. In the life design paradigm, identity formation is a dynamic, lifelong, non-linear process which involves multiple possible realities and selves. ${ }^{41}$ Individuals are considered to be agents, designers and constructors of their lives. The human self is constructed on the basis of narratives through which individuals express themselves and which evolve and transform along with the changing contexts inhabited by these individuals. Narrativity is especially emphasised by Guichard, a co-founder of life design, who perceives people's identities as dynamic, multi-layered, spatial constructs composed of several subjective identity forms (SIFs). SIFs are ensembles of ways of being in the world, acting and cooperating which are integrated with self-perceptions in given contexts. ${ }^{42}$ Individuals construct themselves in both internal dialogues and dialogues with others. Subjective identity forms are anchored in the past, but they affect the way people function in the present and have future anticipations, that is, visions of positions and roles adopted in the future. ${ }^{43}$ Counselling interventions are supposed to help individuals construct various narrative selves, define future perspectives, compose personal stories and makes sense of various activities in life, which unfolds in chaotic contexts.

The life design concept regards career-related issues as interconnected with the whole of life as such in the context of more general existential dilemmas concerning living in the chaotic "postmodern world shaped by a global economy and supported by information technology" 44 . Since individuals' work identities are intimately interwoven with their overall biographies and are "shaped by self-

40 Dupuy, R. (1998). Transitions et transformation des identités professionnelles. Le cas des adultes en situations de formation continue. In Baubion-Broyer A. (Ed.), Evénements de vie, transitions et construction de la personne (pp. 53-54). Saint-Agne: ERES.

41 Savickas, M. L. - Nota, L. - Rossier, J. - Dauwalder, J. P. - Duarte, M. E. - Guichard, J. Soresi, S. - van Esbroeck, R. - van Vianen, A. E. M. (2009). Life designing: A paradigm for career construction in the 21st century. Journal of Vocational Behavior. Vol. 75, pp. 239-250.

42 Guichard, J. (2014). Life designing dialogues: a talk delivered at a research seminar held by the UNESCO Chair for Lifelong Guidance and Counseling in Wrocław on 3 June 2014.

43 Guichard, J. Dialog w koncepcji poradnictwa Life Design..., Op. cit., pp. 57-99.

44 Savickas, M. L. - Nota, L. - Rossier, J. - Dauwalder, J. P. - Duarte, M. E., ..., Op. cit., p. 241. 
organisation of the multiple experiences of daily life" 45 counselling interventions must take into account clients' ecological locatedness as a dynamic whole.

In counselling practice, the simple sequence of diagnosis, recommendation, instruction and guidance is abandoned for the sake of the dialogic co-construction of a holistic life project in which counsellors assist clients. For this reason, supportprovision is not limited to a single meeting but takes a longer time of reflecting on various aspects of life, considering a range of options and testing possible solutions.

Life design counselling is a lifelong, holistic, contextual and preventive approach which seeks to foster and bolster clients' adaptability, narratability, activity and intentionality. Therein, "adaptability addresses change while narratability addresses continuity. Together adaptability and narratability provide individuals with the flexibility and fidelity of selves that enables them to engage in meaningful activities and flourish in knowledge societies" ${ }^{36}$.

Consequently, life design interventions focus on answering questions about humanistic values, examining the goals and meanings of human lives and exploring lives as comprehensive totalities. They are essentially about making sense of biographical episodes and fusing them into coherent narratives, whereby they help clients realise what kinds of active life can make their existence meaningful, valuable, purposive and relevant. ${ }^{47}$

\section{Conclusion}

The brief survey and examination of concepts of helping above suggest that the 'old framework' (meant as a shorthand of sorts, as the phrase encompasses multiple prior approaches which no longer correspond to our chaotic present-day realities) was aligned with the professional system of work organisation, in which people mastered one occupation for a lifetime in lengthy and costly education/training. Consequently, individuals were owners of the skills they had acquired in this way and constructed their identities around their vocational roles. In counselling practice, this translated into measuring individuals' characteristics and comparing them with traits demanded in particular jobs in order to find a fitting match.

The new times with their intrinsic dynamic chaos, which is attempted to be harnessed by automation and digitalisation (and sometimes cyborgisation), call for counselling which is founded on and recognises the multiple contexts, non-

45 Ibid., p. 242.

46 Ibid., p. 245.

47 Guichard, J. (2018). Employability Guidance \& life design intervention: Objectivens, ends and foundations of career and life design interventions. Studia Poradoznawcze/ Journal of Counsellogy. Vol. 7, pp. 235-266. 
linearity and contingency of human lives. In the VUCA world, reality is becoming increasingly complicated and replete with proliferating unpredictable circumstances. Nevertheless, advocates of the chaos theory of careers insist that 'though this be madness, yet there's method in't', i.e. that this complexity also reveals people's dynamic capacity to adapt to and cope with unforeseeable events. If chaos theorists are right, there must be ways to structure the experience of chaos. ${ }^{48}$ It is now counsellors' responsibility to help their clients identify, name and use these ways in designing the future and constructing multiple possible life scenarios, wherein clients are supported in making their lives unified, coherent, meaningful and relevant. Life design counselling helps both discover resources and reinforce them, supports people in coping with transitions, contributes to improving access to decent work and, above all, focuses on facilitating the construction of narratives in which individuals make sense of their biographical experiences. Counselling dialogues bring into relief not only people's needs but also their values, dreams and goals, both those which they pursue and those which they have abandoned or failed to achieve. All this fosters an understanding of inner reference networks and the discovery of what active engagements can make human existence meaningful.

48 Pryor, R. - Brihgt, J. (2001). The chaos theory of careers. New perspective on working in twenty-first century, New York: Routledge; Bright, J. - Pryor, R. (2005). The Chaos Theory of Careers: A User's Guide. The Career Development Quarterly. Vol. 53, pp. 291-305. 